\title{
Nigerian’s Foreign Policy and Vision 20-2020: Any Lessons from the "Asian Tigers?
}

\author{
Cyril Anaele ${ }^{1, *}$ \\ ${ }^{1}$ Department of Peace \& Development Studies, Salem University, Lokoja, Nigeria \\ *Correspondence: Department of Peace \& Development Studies, Salem University, Lokoja, Nigeria. Tel: \\ 234-806-868-3303. E-mail: drcyanaele@yahoo.com
}

Received: October 17, 2016

doi:10.5430/wjss.v4n1p29
Accepted: Noveber 11, $2016 \quad$ Online Published: January 25, 2017

URL: http://dx.doi.org/10.5430/wjss.v4n1p29

\begin{abstract}
Foreign policy is the vehicle used by sovereign states to achieve their national objectives in international relations and among committee of nations. Over the years, Nigeria's foreign policy has been dynamic in response to domestic needs and externalities. One of the pillars of Nigeria's foreign policy amongst several is the promotion of the ideals of Vision 20:2020, through which she seeks to become one of the twenty world economies by the year 2020. The paper's position is that for Nigeria to realize this robust dream, she must situate her economic foreign policy towards creation of strong infrastructures, create congenial development climate, and learn some instructive lessons from the economic miracles of the Asia 'Tigers'.
\end{abstract}

Keywords: foreign policy, development, vision 20:2020, and the Asian 'Tigers'

\section{Introduction}

No issues in our present international relations present concern to nation states as national interest and foreign policy.

Primarily, states situate their national interest on security, peace, sovereignty, economic prosperity, national survival, security and values, social well-being of the people, defence, and promotion of international cooperation. Inseparable and interwoven with national interest is foreign policy maximized through diplomacy. Foreign policy is a well mapped and coordinated strategy used by state for advancement of its national interest(s) and objectives(s) in her external environment, through formal institutions and moralizing principles for such pursuits. The tact and skill used for international relations is diplomacy. It is the tool/language states use for packaging and promoting of national interest and foreign policy in their external relations with other states and non-state actors in international relations.

In effect, so to speak, foreign policy and national interest are coterminous and reciprocally reinforcing. Seen in this sense, as a core substance of foreign policy, if it to be productive, must be responsive to trends and realities in the constantly changing world. Put succinctly, foreign policy is the pursuance of domestic interest in a country's external relations. Thus, its formulation and execution must translate into linkage with national interest/objective.

Scholars long in international politics and internalization of global economy through globalization now emphasize on confluence of politics and economy, illuminated through increase in a state's wealth and power. The world without boarders have compelled states to re-examine their foreign policies, in the light of the realities and dictates of globalization. What has emerged from this development is the pursuit of economic game in world politics, states play on one another, for balance of fiscal power, now viewed as important as national security and balance of military might, as the world is transforming from roundness to flatness.

To be relevant to these economic stark realities, serious nations have spawned a resurgence of interest in building a buoyant and robust economy, as a supra-structural heart beat of other sub-structures critical to political stability, social cohesion, security and general well-being of the citizens, which they seek to achieve vie integration of economic goal into their foreign policy objectives. The inherent gains in economic prosperity, and its attendant multiplier effects in all the indices for measuring development, have made nations committed to development to integrate economic diplomacy into their foreign policy, for the purpose of fast - tracking national development.

Nigeria's foreign policy and how it has been engineered to meet the challenges of her development viz-a-viz Vision 
20-20-20, and the lessons she can learn from the "Asian Tigers" economic miracle are the preoccupation of this work.

The work is divided into six but inter-related parts, namely;

1) Nigeria's foreign policy: Continuity and change

2) Nigeria's Troubled Journey to Development, 1960-1992

3) Nigeria’s Foreign policy and Globalization Pains

Vision 2:2020: Magic Wand, Myth or Reality?

4) Lessons from “Asian Tigers.” The methodology it employed is critical unit analysis, using historical method for its presentations.

With barely four years away to the year 2020, findings from this work authenticates the general assessment of the supposedly vision as a mere shadow, a political trick to hoodwink Nigerians into seeing the poor performing government as having repented of its infliction of Nigerian citizens with grinding poverty and embarrassing under development, by promising to transform Nigeria into one of the twenty largest economies in the world by the year 2020.

As I had argued elsewhere (Anaele:2014), it is a music concert without instrumentation, and presumably an imaginary palliative measure for long term suspension of the anger and disillusionment of the pauperized masses, now at a critical juncture of implosion into melee.

What informed this conclusion in because Nigeria has neither put in place the germination of infrastructural facilities, fiscal and monetary policy, intellectual wealth, budgetary discipline, good governance, nor the relevant political will and technology for realizing Vision 20:2020, now four years in the offing.

\subsection{Nigeria's Foreign Policy: Continuity and Change}

Nations script and tailor their foreign Policy to capture their national interests and national objectives which they illuminate in their dealings and interactions with other states. Wittkopt (2003) defines it as the integration of national interests, national objectives, and national values a nation seeks to achieve abroad, through its designated state officials, and the designing of appropriate instrument for their attainment. In the contention of Ogwu (2005), foreign policy objectives are range of intended actions adopted by sovereign actors for the purpose of influencing the behaviour of other sovereign actors in the international system. Foreign Policy refers to the specific decision-making aimed at protecting, maximizing and promoting the prescribed national interest of the given state (Okolie) 2009 p.5.

In his policy analysis, Essoh (2014) cites Histon definition of policy as what the government chooses to do, and what it chooses not to do. The inference from this shows foreign policy as representing viable and feasible strategies for state action, and goal oriented, through which it seeks to advance national interest into her external environment, within the frame of internationally accepted norms.

......as an act of internationalizing domestic resolve, foreign policy takes into cognizance competing domestic choices, demands and constraints, and relates same to dominant global norms/principles, expectations and practices (Okolie, 2014) PP816-17.

Ajibola (1978:1) conceptualizes foreign policy in terms of analysis, assumptions, decision among alternative choices and approved actions for successful and practical implementation of the accepted course of action.

Earlier, I had argued (2013) on the chameleonic nature of foreign policy, arising from the necessity to respond to the changes and developments in our ever changing world, unpredictable by the growing complexities and conundrum in world politics. Our present international system is skewed against the emergent states at a disadvantageous line and requires a thorough grasp of global geo-politics, riddled with contraptions and contra-fictive surprises.

Anaele (2013:65) argues on the fluidity of foreign policy and its analytical difficulties. Saliu (2006), Utete (1985), Hosti (1995),Garba (1991), Morgenthan (1973) among several other scholars emphasize on the strength of the economy, political will, quality of leadership, national aspirations, type of government and the international environment as dynamics influencing and re-inventing external relations. Nigeria, as every other nation, formulates and implements her foreign policy in tandem with her national interest and state objectives.

Foreign Policy making and execution in Nigeria is a long historical process with root in the Nigerian's independence on October $1^{\text {st }}$, 1960. Though, some have argued on 1946 as the beginning point of Nigeria's foreign policy using 
Arthur Richard's Constitution as their evidence. Such an argument is inappropriate and untenable, by the fact that before Nigeria's independence in 1960, she was part of the British Empire. All her external relations were conducted by Britain, controlled and manipulated by imperial interests.

At independence, the foci and thrust of Nigeria's foreign policy as articulated by the Balewa administration were as follows:

1) Maintenance of peaceful and cordial relations with all nations, big and small,

2) Championing of African issues...

3) Maintenance of friendly and cordial relations with Great Britain

4) Contribution to the maintenance of world peace, through the instrumentality of the UN and participation in its peace keeping operations

5) Membership of multi-lateral organizations that have functional relevance to the country, especially the UN and the Commonwealth;

6) Non-alignment with any of the existing ideological and military power bloc;

7) Adherence to the principles of the UN as basis for relations with other independent states as foundation for peaceful world order;

8) Respect for the sanctity of African boarders inherited from colonial masters, in spite of imperfections and disadvantages,

9) Non ambition for territorial or expansionist design against its neighbors,

10) Commitment to speedy economic and technological development of the African continent, as a political priority, and

11) Opposition to any political union of uncertain future (Fawole, cited by obi 2006 PP 109-110).

From the above, we can make the following generalizations

1. That the Balewa foreign policy was Afrocentric

2. Pro-west and

3. Non-alignment as demonstrated by his distaste for Anglo-Nigeria Defence pact of 1960 which would have allowed Britain to operate an air base in Nigeria.

4. It was hollow on technology

Balewa set the principles of Nigeria's foreign policy which has served as compass for successive governments. His morbid aversion for communism restricted his policy options and concomitantly limited the gains Nigeria could have tapped from a genuine non-aligned posture.

A close look at Nigeria's foreign policy shows a trend in continuity, and consistency, despite changes in government. From Gowon administration 1966 to the present, Nigeria's foreign policy has retained its fundamental tenets, except minor paradigm shifts, during the regime of Gowon, who in desperate need for arms, to prosecute the Nigeria's civil war broke the country's isolation from the Eastern bloc, notably the Soviet Union. Other minor shake-offs were during the Murtala government (1975) and Obasanjo (1975-1979) caused by Britain's position on the Angola crisis and her endorsement of support benignly to Apartheid South Africa with her US ally.

The others were the seemingly western opposition to Gen. Babangida, former Nigeria's military Head of State, for his annulment of Nigeria's Presidential election, June 12, 1993; because of his self-succession bid and Gen. Abacha (his successor) unprecedented abuse of human rights which made the West classify Nigeria as a pariah State.

Abacha's regime, 1993-1998 was isolated by Nigeria's Western traditional friends and in his search for new allies, he fraternized with ruthless leaders like Gaddafi of Libya, Barre Mainassara of Niger Republic and Omar Bashir of Sudan. Nigeria's military president, Gen. Abdul Salami (1988-1999) and Obasanjo (1999-2007) who succeeded Abdul Salami after Nigeria' transition to civil rule, pursued fence - mending diplomacy in the west, but did not depart from the crucible of Nigeria's foreign policy, except for minor changes reflecting the mood of the nation. Specifically, Babangida and Abacha as was widely believed gave unreserved commitment to the sustenance of ECOWAS Monitoring Group, ECOMOG, not because of their passion for peace in West Africa, but to have at their beck and call, a regional force to rely on, should armed conflict arise from their self -succession bid over regime legitimacy question. 
The military opportunists from Gowon to Abdul Salami were void in emotional intelligence. All Nigeria's military Heads of State embarked on wasteful "spray diplomacy," picked the bills on African issues, but lacked the capacity and intelligence to confer greatness on the nation, through feasible development. In the contention of Atte (1990) domestic economic imperatives are the most vital determinants of national interests, and therefore of foreign policy priorities. Badangiba's structural Adjustment Programme SAP 1986 was an international monetary fund IMF deceit, a cure worse than the disease, ending up with Nigerians writhing under pains of poverty, collapse of critical social services and the economy.

However, Abacha in 1996 enunciated the Vision 2010, a socio-economic blue print targeted at improving the quality of life for all Nigerians, through eradication of poverty, sustained human development, local capacity building and industrialization by the year 2010. Abacha died unsung on June 8, 1988. His demise was trailed by accusation of massive looting of the public treasury and notoriety as the worst despotic military ruler in Nigeria, Obasi, 2001 P.4. If Abacha had survived beyond 2010, one wonders if his incurable craze for stealing and looting can launch Nigeria into development.

Presidents Obasonjo (1999-2007), Yar’ Adua (2007-2009), Jonathan (2009-2015) anchored Nigeria's development on what was later reduced into an economic thought, branded as Vision 20:2020.

\subsection{Vision 20-2020: Magic Wand, Myth or Reality?}

The vision 20:2020 policy originated from Obasanjo administration (1999-2007). It was introduced in 2007 toward the end of his administration with concrete actions for its realization.

Obasanjo situated V20:2020 on National Economic Empowerment Development Strategy NEEDS. On assumption of office 2007, Yar'Adua reframed it into Seven Points Economic Agenda namely: stable polity, macro-economy, infrastructure, education, health, agriculture and manufacturing. The target was to have a peaceful, cohesive and stable nation by year 2020, a robust macro-economy, stable and globally competitive, with a GDP of not less than $\$ 900$ billion and a per capita income of not less than $\$ 4000$ per annum.

Others are efficient infrastructural services, such as roads, railways, power, water-ways, air transport for full mobilization of all economic sectors- oil and gas, agriculture, solid minerals and manufacture, a modern and sound education, capable of offering all citizens the opportunity for realizing their potentials and self-fulfillment to optimum, and competency in intellectual wealth, man-power development, efficient health-care delivery for substance of life expectancy of not less than seventy years, reduction to the minutest level incidences of infection diseases, like malaria, HIV/AIDS and other life threatening diseases, through primary and tertiary health-care. Modernization of agriculture through mechanization and exploitation of the enormous agricultural resources of Nigeria for food security and foreign earnings. It also envisioned a technologically driven economy for mass production of goods and services with international competitiveness, to reduce importation and accelerate exports.

The vision short and long term mandates are to make Nigeria a "large, strong, diversified, competitive, technologically enabled economy, for effective harnessing of the talents and energy of its people and responsibility.

Exploit of its National Endowments to Guarantee a High Standard of Living and Quality of life to its citizens”. The broad strategy for achieving the vision is by the optimal use of Nigeria's vast human and natural resources. These, the vision intends to translate into rapid economic growth, social and economic development, with undiluted emphasis on job creation, reduction of poverty, knowledge-based economy, driven by information technology and aggressive reversal of duality and informality of the economy into a formal economy to increase Nigeria's GDP.

Specifically, the vision is based on three basic thrusts, namely;

1. Creation of a successful economic platform for solving the obstacles to Nigeria's economic growth, competitiveness and national development.

2. Boosting the private sector on non-oil sector as foundation for economic diversification.

3. Growing and solidifying government's capabilities to translate national strategic development intent into action and implementation.

Some of the critical spheres of vision 20:2020 are,

1. diversification of investments in critical infrastructures

2. expansion of the private sector on non - oil resources

3. paradigm shift on revenue generation 
4. strengthening the war against corruption

5. security

6. reforms in the social fiscal sectors.

To achieve the vision, the federal government created the National Council on Vision 2020 for provision of leadership direction and mobilization of the citizenry. The Council is to use a bottom-up leadership approach that will ensure ownership by all stake-holders. Other Committees such as the steering Committee on Vision 2020, the Stake - holders Groups, (acting as engine of the visioning process) with the Technical Working Groups Committee providing technical assistance and support to the National Steering Committee. All the committees report to the National Council on Vision 2020

The implementation and its structure also included the representatives of the three arms of government, representatives from the Private Sector, namely; the Economic Summit Group, the Nigerian Association of Chambers and Commerce, the Nigerian Labour Congress, Industries, Mines and Power, the Nigerian Economic Society, to assist in formulating a sound economic policy direction.

By incorporating the private sector and its bottom-top leadership approach, one would have expected that vision 2020 could have represented a new direction in economic thought and holistic development. But in this, it failed. For its continuity, President Goodluck Jonathan (2010-2015) rebranded the vision as Transformation Agenda and maintained its original script with minor changes to reflect current realities.

Vision 20:2020, therefore, is an economic blue-print, robust and holistic in strategy, designed to accelerate economic development and transformation of Nigeria into the top twenty developed economies in the world.

A factorization of the vision reflects at a glance the following constituents-social, economic, institutional and environmental dimensions. Others are, emphasis on the private sector, as main engine for economic growth, concern for Nigeria's poor global rating on economic prosperity and international competitiveness, turning Nigeria into the league of twenty foremost economies in the globe, bottom-top approach, power and energy, and the last but not the least, are land reform and improvement of Nigeria's image through socio-political, economic and cultural re-branding.

The conclusions from all these are that it aims at positioning Nigeria at the core and on the nomenclature of the first twenty largest and industrialized nations in the world.

By becoming one of the twenty largest economies globally, Nigeria is expected to do what such nations in the league of the twenty like Germany, Canada, France, Belgium, Italy, Greece, Denmark, Norway, Netherlands, Switzerland, Poland, Russia, Austria, Spain, Turkey, Australia, India, Indonesia, Malaysia, and Brazil have the capacity of doing.

\subsection{Challenges}

With barely four years to year 2020, one wonders if vision 20:2020 is realizable. What has brought about this skepticism are the serial persistence of absence of science and technological development, inadequate infrastructural facilities, weak institutions/institutional decay, moribund educational sector, neglect on man-power development, policy inconsistency and discontinuity, absence of virile and proficient fiscal and monetary policy, lack of budgetary and fiscal discipline, embarrassing high rate of corruption, persistence of mono-economy, lack of political will, good governance and visionary leadership, high rate of poverty, unemployment and high rate of preventive diseases, insecurity, emphasis on indigene ship, instead of citizenship, lame power sector, over-centralization, over-dependence on the west, instead of inward looking, wrong values, neglect on mass mobilization and lack of patriotic spirit, implementation by public officers known for unnecessary bureaucracy and corruption, The worst hitting the dream is Nigeria's present economic recession, worsened by mass looting of public treasury. These are Nigeria's internal contradictions and the challenges to the realization of the dream

\section{Nigeria's Troubled Road to Development}

Nigeria has the vast human resources and natural resources, which if properly appropriated, have the potency for realization of the vision. At moment, her vast human and natural resources have been put to waste and largely untapped and under-utilized.

Before Vision 2020, Nigeria had made several attempts at framing and visioning socio - political and economic development. In this regard, not less than five national development plans have been experimented on and launched, but each yielded worse results than its intents and predecessors. 
The first National Development Plan 1962-68, was comprehensive with focus on the development of private and public sectors. This was followed by the second National Development Plan 1970-74, aimed at post-war reconstruction, situated on five cardinal objectives; namely; a strong and self reliant nation, a great and dynamic economy, a just and egalitarian society, a land of pride and full opportunities for all citizens, and a free and democratic society. The Third National Development Plan, 1975-80 modified the second National Development Plan by increasing per capital in-come. It also included even dispersal of in-come, reduction in unemployment, increase in high level man-power, diversification of the economy, even development, and indigenization of the economy. The Fourth National Development 1981-85 was an improvement of earlier ones before it by harmonizing them into specifics, such as even distribution of incomes, balanced development of different sectors of the economy, greater self reliance on technology, increased citizens' participation in the ownership, management and production activities and reduction in the dependency of the economy on a narrow circle of economic activities. One common characteristics of the First, Second, Third and Fourth Development Plans was that they were produced by Nigeria planners, who also failed woo fully in their implementation.

The successive Fifth Development Plan expected to run from 1988-92 was jettisoned and replaced with the World Bank -International Monetary Fund Structural Adjustment Programme SAP 1986-92. SAP worsened the already poor living conditions of majority of the populations, save the elitist class it was intended to prosper. To overcome the serial nagging persistence of poverty and under-development, and to consolidate earlier gains (hardly any), government in 1989 relinquished from its ritual conceptualization of fixed five years development strategy. Instead, it came out with three years "rolling plan" 1990-92.

This period swathe propagation of catchy and salivating phases like "Health for all by year 2000," Housing for all by year 2000", and food for all by year 2000", etc. Disappointedly, none of these ambitions was impressively and largely realized to win faith in government. Abachas' Vision 2010 was another comprehensive Immediate, Short, Medium, and long-term action plan for stimulation of economic growth and transformation of Nigeria into a developed Country. However, Vision 2010 did not last, following the sudden death of its originator, Gen. Abacha, for its analytical assessment, it however, became the bench - mark for Vision 20:2020.

From the forgoing explorations, we can rightly argue that the problem of Nigeria is not lack of planning, but continuity and implementation. In spite of her robust economic and development plans, Nigeria has continued to remain at the slum of the global economy with vast majority of her human population living in starvation, poverty, unemployment, disease, ignorance, ill-clothed and ill-housed, reflecting conspicuously paradox of poverty in the luxury of the elites.

Against the backdrop of earlier development plans, and without sounding skeptic, and with four years to 2020, vision 20:2020 is a robust Vision of the mind, without any convincing evidence of action, to show that Nigeria is marching close to development, not to talk of being one of the twenty developed world economy. As I earlier said, it is music without instrumentation, crafted to divert the anger of the pauperized masses, by soothing their frustration with promise of utopia and better years ahead. One wonders what excuse Nigeria's authorities will give at the dawn of 2020, if these dreams are not realized, as they definitely are unrealizable. Then and only then will Nigerians realize the broken promises and deceits of her ruling class.

\subsection{Globalization and Vision 20:2020}

The current of globalization is steering and directing the course of international economy. It has assumed a central stage for all nations (big or small) to dramatize their economic growth and levels of development. This reality has integrated states' economies into a singled "Villagized" but boarderless economic order, with unequal gains and losses.

Globalization of World economy, labour and production have worsened the centre-periphery relationship, with the developed nations at the core, reaping bountiful harvest, and the developing ones at the periphery, going home with the crumps from this new economic order. This has widened further the in-come gap between the two sets of countries.

It is a trade trick and economic conspiracy for institutionalization of economic and imperialist greed of the West; by ignoring the morality of relative gains for all, and favouring absolute gains for few. Increasingly, what it has produced is unequal distribution of access among states arising from the openness in the international market.

Nigeria's domestic political economy cannot offer her the capacity to compete favourably and gainfully in the international market, itself an engine of economic growth.

Globalization is the most ubiquitous in the language of international relations (Ostry, 2001), a euphemism for 
capitalism (Petras and Veltmeyer 2004), a multifaceted phenomena, inter-connectivity between human and material relations, and the increasing rapidity through which they take place (Held and Graw (2003), integrating everything with everything else; markets, finance, and technology in a way that shrinks the world from a size minimum to a size small....... (Friedman and Kaplan 2002, p. 64).

Globalization has increased the economic game nations play on one another in international politics. The inter-connectedness in capital, people, and exchange as they expand to assume cross boarder consolidation has a cost and profit. Developed economies take the lion part of the profits. Developing counties like Nigeria receive miserable share from the openness in the internationalized economic system.

This new friend undermines states' regulatory capacity and autonomy in the control of their international economic affairs. Each country gets as it contributes to the system.

Nigeria has not much to contribute to the system because outside oil, she has nothing else to compete with in the global economy. She still relies heavily on traditional mode of production. Her business environment is discouraging to Foreign Direct Investment, FDI and Finance Capital, arising from outlandish laws, political instability, insecurity, corruption and collapse of critical infrastructures, like power, roads, railways, water-ways etc that reduce cost of production. Consequently, globalization stress and pain in Nigeria will certainly debilitate her efforts for V.20:2020, except she remodels her foreign economic policy toward increased economic fraternity with the medium in-come countries of Southeast Asia to understand the measures they took for their economic miracle and its attendant national development. This is instructive to Nigeria still crawling toward development.

The disparities in technological gap account largely for the meager profits Nigeria and other developing nations receive from the globalized economy. However, countries of the East and Southern Asia that shared similar experiences with Nigeria have moved away from under-development and poverty to rival the levels of prosperity in the Global North. Except perhaps china, Japan, and Siam (Thailand), all the Countries of Asia were conquered and brought under European Colonialism and imperialism. Like Nigeria, the countries of Southern and East Asia before and after independence were enmeshed in embarrassing illiteracy, agrarian economy, disease, hunger, with majority of the population drenched in 'shouting' miseries and grinding poverty. Political, social and economic instability, and deeply rooted, and often Precambrian traditions constituted constrains to technological and social advancement. These are basic socio-economic features of Asian Scene. As in Nigeria, Asia was as heap of loose sand, without the cement of patriotism, to bind its people into social cohesion, needed for nation-building and progress.

Today, these features cannot be said to be the libel of southern and East Asia counties. Interesting, they are now in revolt against bondages of the past, against poverty, ignorance disease, under-development and dependency syndrome. Their colonization by the West, though a tragedy, gave the people a renaissance in idea, ideal, faith, and confidence in themselves, and a vision for a better future.

Southern and East Asia now referred to as the Global East in World Politics have positioned themselves to compete with the Global North in economic prosperity, export of manufactured goods of all sorts, including provision of services and expertise in communication and information technology/processing.

This awful economic miracle is true of the four countries fondly called the Asian 'Tigers.' The four are South Korea, Singapore, Taiwan and Hong Kong (SSTH). Japan paved the lead for China, and India to follow. The Asia 'Tigers' found in Japan, China and India (Asian 'Dragons') as example and model. Here Livy's thesis quoted by Edet (2013:38) is instructive that, "in history you have a record of the infinite variety of human experience plainly set out for all to see; and in that record, you can find for yourself and your country both examples and warnings, find things to take as models, base things, rotten through and through, to avoid."

Today, the nine countries that constitute the Global East, namely; Japan and China (the leading economies), the four Asian 'Tigers,' India, Malaysia, and Thailand together account for one-third of the total global gross national in-come, adjusted to purchasing power parity PPP (WDR 2009:352-353).

The success story of these newly industrializing countries and their transformations into the league of industrialized prosperous nations can instill faith in Nigeria, as an example for modeling her development strategies. Development is complex, and transcends beyond the surface of development planning, to include the intangibles, such as good governance, probity, stable social and political system, political will, vision, cultural pattern, intellectual wealth, national character, peace and several other basic factors. The following but inter-related questions are:

(i) How did the Asian 'Tigers' that emerged from the burden of colonialism as Nigeria develop fastly? 
(ii) Was it an act of favour by nature which was denied to Nigeria, or conscious efforts of her human population and leadership?

(iii) If it were the product of her human population and leadership, what strategies did they use?

(iv) What lessons can Nigeria learn from the economic miracles of the Asian 'Tigers'?

This will form the falcon and the concluding segment of this discourse.

\subsection{Lessons from the Asia 'Tigers'}

Economic historians disagree over the cause of economic growth. Some emphasize on the 'supply' side of the process, others on 'demand' side of growth. The former focus on factors of production-labour, resources, skills, capital and technology (method of production) complemented by the economy, to increase production out-put.

The latter identify the dynamism of economic expansion as catalyst for swelling demands for goods and services. They sought to factorize by identifying why and how demand grow, as direct consequences of resources, technology, capital and labour. To grasp how the Asian "Tigers" rose from "nobody" to 'somebody', and obscurity to visibility on the ladder of industrialization, economic growth and prosperity, we must look at demand and supply, resources, labour, technology, capital, political leadership, patriotism, sacrifice, and banking system/education.

Their success began with turning of primaries into manufactured goods that met international standard, through the use of technology. The spring board was agricultural revolution for provision of finances for industrial take-off and diversification of the economy. The Asian 'Tigrs'realized the importance of labour as catalyst for national development. Natural resources are critical to the economic growth of the Asian 'Tiger'. But beyond natural resources, they used human capital to turn their resources into tangible and intangible products for export. Her natural resources would have remained unprofitable, if they have not used human capital to turn them into export earnings. To realize this, they modernized their education system.

Education is a major player in development. Modern economic development depends largely on creation of literate, intellectual, professional, disciplined labour force, used interchangeably as "human capital.” Economists call it "on sheer numbers of workers." In Asian 'Tigers', such a labour force was created by sound, disciplined, result oriented public school system. Their products are as skilled and proficient as those of Europe and America, and sometimes better. One benefit of this was outsourcing of jobs by Multi National Corporations, MNCS to skilled Asian workers, good enough for the job as those of the West, but settled for low wages. These outsourced competent skilled Asians, learnt and domesticated the mystery of industrialization, hidden in the hands of MNCS. At home, these skilled professionals combined what they gained from their working experiences in MNCS and those of Japan, India and China and domesticated them to energize industrialization and export led economy and economic diversification.

Technology is the anchor of industrialization, mass production of goods and services, job creation, reduction in poverty and unemployment, fight against food insecurity and acceleration of economic growth and development. It is the direct outcome of education for cultivation of "intellectual wealth". The Asian "Tigers" discovered the relevance of education to development and economic growth. They patterned their school system toward problem solving and pragmatism.

The growing labour force of the Asian "Tigers" was matched with a growing supply of capital. Capital, as economists use it, is not just money, but money invested in machines, brains, barns, roads, railways, air - transport, mines etc. It is money invested in "tools" to produce other commodities. Today, capital has been expanded in meaning to include skills people acquire for the improvement of their ability to produce goods and services. The Asian "Tigers" realized this fact and grabbed it firmly. When properly invested, which of course they did, money deepens economic growth. That was exactly what they did with their savings and money. The question to ask here is, 'from where did they source the money?' it came from savings and from abroad in form of implements, credits, foreign capital, aids and loans transparently utilized.

.Banks and banking system as financial institutions play important role in economic and industrial development. The Banks and banking system of Asian "Tigers" energized the growth of private capital, aided in the investment ambition of focused business entrepreneurs, the stock market, and economic promoters, thus accelerating the growth of their nations' capital.

Good governance is the foundation of development. In its absence, the resources and human capital of a state cannot be maximized.

It will be wrong and crass distortion of facts to access Asian's political system on its desirability or otherwise with those of advanced stable democracies of the West, or through identical spectacles. The nagging problem of poverty, 
the ruggedized social structure and their lamentations over colonial exploitation and desecration of their values are green in their sub consciousness. It is not surprising therefore, that in order to enshrine good governance, they opted for home groom system of government, which took into cognizance the obstacles to national development, which they sought to overcome through the instrumentality of government. Thus, they judge any political system, not by name or by Western model, but by its general effects on their living conditions, and reduction in in-come disparity. With exception of Japan, India, Philippines and Malaysia, southern Asian counties are most often either authoritarians regimes, embryonic or "guided democracy." No matter the deficiencies in their political system by the Western definition and standard, the Asia "Tigers" demonstrated stardom in good governance by mobilizing their citizenry, reduced corruption, and over-threw poverty through export-led economy, sustained by industrialization and uncommon political will. These, they complimented with expansionist economic foreign policy, sustained by strong institutions and visionary leaders with charismatic appeal to the masses. The four Asian "Tigers" are collaborators rather than rivals in their competition with Japan, India, China and the West for markets and raw materials. They unsung price of national development is sacrifice. In this sense, they made sacrifice in order to grow.

National building is a process involving concerted efforts and sacrifices of the people. It demands for patriotism and subordination of self and ethnic interest to national interest. Asia "Tigers" did not get to where they are today by sheer luck, but through the unquantifiable sacrifices of the leaders and followers. The rulers and the ruled are more concerned with what they can give to their country than what to get from their country. Nigeria can learn useful lessons from the Asian "Tigers" for her vision for development.

The two sets of countries share many similarities. These are;

(1) Both emerged from colonialism

(2) They had same challenges on development, though with varying negligible degrees.

(3) Both have mineral and human resources

(4) They are confronted with challenges of ethnic and religious diversity, and backward traditions that impede social growth.

(5) They are fledging democracies.

(6) Earlier, the Asia “Tigers" as Nigeria were trapped in the web of poverty and under-development, dependency and mono-economy. Today, they have moved away from under-development through the various strategies I had earlier marshaled out in this work.

Lessons for Nigeria, using the Asia "Tigers" model are many when studied for the purpose of domesticating their economic miracle for Nigeria's freedom from underdevelopment. The first step they took was to diversify their economy, using agriculture as the spring-board. Educational transformation to them was a necessary weapon for social and economic transformation. They made their school system relevant to national needs and aspirations. Nigeria should aspire for home groom technology to catalyze industrial revolution for transformation of her primary goods into finished products as was the case with the Asian "Tigers'. The gains of technology for acceleration of production are obvious.

Other areas where she can use the Asian model, though with modifications to capture her peculiarities are banking and financial reforms, provision of critical infrastructures, creation of investment friendly environment, security, viable economic domestic and foreign policy, man-power development, cut in cost of governance, accountability and de-regulation of the economy, instilling of spirit of patriotism, fiscal discipline, and values. She has to deepen democracy, fight corruption head-on and embark on fruitful political and economic reforms like the Asian Tigers. Nigeria, as the Asian 'Tigers' did, must facilitate the emergence of vibrant private sector capable of existing, without over reliance on government patronage and finances. What obtains in Nigeria today are lame private sectors, surviving on state patronage, and at best are extension of 'corruption wing' of government for the enrichment of the political elites. They are "disguised' political parties branded as private companies. Thus, they are different from Asian private sector which works to transform their various states from consumer to productive economy.

Nigeria's human population, unlike in Asia “Tigers”, is badly politicized, through the institutionalized quota system of admission into federal institutions of learning, and the use of federal character for recruitment into federal employment. This practice has deprived Nigeria of her best brains and professionals needed for nation building. 


\section{Summary and Conclusion}

The paper through critical analysis examines Nigeria's foreign policy, her Vision 20:2020 (a development blue-print to make Nigeria one of the twenty top global economies by year 20200) and challenges to the realization of the vision. It compares Nigeria's successive development blue-print with those of Asian 'Tigers' success economic story, and how it can serve as a lesson for Nigeria, still trudging on development. The work observes, contrary to all pretenses that Nigeria, in spite of her much publicized theoretical ambition for development, is still caught in the web of under-development. It looked at the various obstacles to Nigeria's development and identified them as systemic pathological defects. It agrees that Nigeria's foreign policy has under-gone some fundamental changes, in response to time and needs, but posits that these have not translated into tangible profits. In its examination of Nigeria's development strategies over the years, it observes that Nigeria has demonstrated lack of ableness in the implementation of her development plans. She is the best of good in conceptualization of development plans in theoretical terms, but has failed to concretize them into practical reality. The paper highlighted the obstacles and challenges to her troubled journey to development, and argues that they are not insurmountable, going by the Asian 'Tigers' success, which she shares many similar colonial experiences. It itemized the various approaches used by the 'Asian Tigers for their success story in development and argues that Nigeria can use them as bench mark for her development, still at tutelage. In conclusion, the work dismisses Vision 20:2020 as untenable, but at best, theoretical development rhetoric conceived without the matching implementation strategies for its actualization.

\section{References}

Ajibola, W.A. (1978). Foreign Policy and Public Opinion. University Press.

Akira, I., Lazzerini, E., Kopf, D., \& Miller, Wet al. (1995). The World of Asia (2 ${ }^{\text {nd }}$ Ed.). Illinois, USA: Harlan Davidson.

Anaele, C.O. (2014). National Interest and Challenges of Global Peace. International Journal of Contemporary Studies, 1(1), 65-88.

Chant, S., \& Cathy, M. (2009). Geographies of Development in the $21^{\text {st }}$ Century: an Introduction to the Global South. New York: Edward Elgar Publishing.

Essoh, G. (2014). "public policy Analysis," lecture delivered during the Public Administration Students Week, Salem University, Lokoja -Nigeria.

Friedman, T., \& Kaplan, R. (2002). States of Discord. Foreign policy, 12, 64-70. https://doi.org/10.2307/3183391

Garba, J. (1991). Diplomatic Soldiering. Ibadan: Spectrum Books.

Held, D., \& Mc. Graw. (2003). The Great Globalization Debate” in David Held and Anthony Graw (eds.) The Global Transformation Reader. Cambridge: polity Press.

Holsti, K.J. (1995) International Politics: a Framework for Analysis ( $7^{\text {th }}$ ed). New Jersey: prentice Hall

Obasi, E. (2001). The vision 2020 Agenda in Nigeria's Development. Owerri: New Vision Publishers.

Ogwu, U.J. (2005). Introduction: An Overview. In U.J Ugwu (ed.), New Horizons for Nigeria in World Affairs. Lagos: NIIA.

Okolie, A. M. (2014). Understanding Nigerian Foreign Policy in the $21^{\text {st }}$ Century. In C.N Oguonu (ed.), Management and Development: A Contemporary Reading in Public Administration. Abuja: Premium Publishing House PP 816-819.

Okolie, A.M. (2009). Economic Diplomacy and the conduct of Nigeria's Foreign Policy under Obasanjo's Administration. Nigerian Journal of International Affairs, 36(2), 5.

Ostry, S. (2001). Review of the Challenge of Global Capitalism by Robert Gilpin. American Political Science Review, 95, 257-58.

Petras, J., \& Veltmeyer. (2004). A system in Crisis: The Dynamics of Free market Capitalism. London: Palgrave

Saliu, H.A. (2006). Essays on Contemporary Nigeria Foreign Policy (Vol.1). Ibadan: Vantage Publishers.

Utete, C. B. (1985). Foreign Policy and the Developing State. In J. C. B. O. Ojo, et al., African International Relations. London, New York, Lagos: Longman.

Williams, Glyn, Paula, M., \& Katie, W. (2009). New Geographies of Global South Development Areas in a changing 
World. New York: Taylor \& Francis.

Wittkopt, Eugene R., Christopher M., \& Charles W.K, Jr. (2003 Revised 2008). American Foreign Policy. California: Thomson Wadsworth.

World Bank. (2009). Atlas of Global Development ( ${ }^{\text {nd }}$ ed.). Washington D.C.: World Bank. 